\title{
Classic Antiphospholipid and Antiphosphatidylserine Antibody Profile in Suspected Antiphospholipid Antibody Syndrome Patient
}

\author{
Gambaran Hasil Pemeriksaan Antibodi Antifosfolipid Klasik dan Anti \\ Fosfatidilserin pada Pasien yang Dicurigai Sindrom Antifosfolipid
}

\author{
Angga J Suryadi, Kanadi Sumapradja \\ Department of Obstetrics and Gynecology \\ Faculty of Medicine Universitas Indonesia/ \\ Dr. Cipto Mangunkusumo Hospital \\ Jakarta
}

\begin{abstract}
Objective: To compare the classic examination results of antiphospholipid (aPS) and antiphospatidylserine (aPL) antibody profile to establish the diagnosis from suspected antiphospholipid antibody syndrome (APS) patient in order to state the subsequent treatment strategies.

Method: This descriptive cross-sectional study design was conducted at outpatient clinics of Dr. Cipto Mangunkusumo Hospital (RSCM) from January to December 2015. The laboratory test was held in Clinical Pathology Laboratory RSCM/Faculty of Medicine Universitas Indonesia (FKUI) and in corporation with Prodia laboratory.

Result: All of normal patients did not have positive result in any laboratory examination (Lupus Anti-coagulant (LA), anticardiolipin $(\mathrm{aCL})$, anti- $\beta 2$ glycoprotein I (anti- $\beta 2 \mathrm{GPI})$, and aPS). In patient suspected APS, 11 (37.1\%) patients had positive aCL, 7 (25.9\%) patients had positive anti- $\beta 2 \mathrm{GPI}$, and $11(37.1 \%)$ patients had positive aPS. The most positive cross laboratory examination was between aCL and aPS (25.9\%). In this study, we found the most positive test result was aCL and aPS (62.9\%). From this study, suspected APS patient who had negative result in classic laboratory examination, but showing the positive result in aPS was in $5(18.5 \%)$ patients.

Conclusion: All normal pregnant patients do not have any positive classic examination and aPS. Meanwhile, in patients with suspected APS, less than $20 \%$ patients show positive result of aPS with negative result in classic laboratory examination.

[Indones J Obstet Gynecol 2016; 4-3: 138-141]
\end{abstract}

Keywords: antiphospatidylserine, antiphospolipid syndrome

\begin{abstract}
Abstrak
Tujuan: Untuk memberikan perbandingan hasil dari pemeriksaan klasik antibodi antifosfotidilserin (aPL) dan antifosfolipid (aPS) untuk menegakkan diagnosis tersangka sindrom antibodi antifosfolipid sehingga dapat menentukan rencana tata laksana berikutnya.

Metode: Penelitian dengan desain potong lintang deskriptif ini dilakukan di Rumah Sakit Dr. Cipto Mangunkusumo (RSCM) pada bulan Januari 2015 sampai Desember 2015. Pemeriksaan laboratorium dilakukan di laboratorium Patologi Klinik RSCM - Fakultas Kedokteran Universitas Indonesia dan laboratorium riset Prodia.

Hasil: Semua pasien hamil normal tidak memiliki satu pun pemeriksaan klasik (antikoagulan lupus (LA), antikardiolipin (aCL), anti- $\beta 2$ glikoprotein I (anti-32GPI) serta aPS) yang positif. Pada pasien yang dicurigai APS, 11 (37,1\%) pasien memiliki pemeriksaan aCL yang positif, 7 (25,9\%) pasien memiliki pemeriksaan anti- $\beta 2$ GPI positif, dan 11 (37,1\%) pasien memiliki pemeriksaan aPS yang positif. Hasil silang pemeriksaan aPL positif terbanyak adalah antara aCL dan aPS yaitu sebesar 25,9\%. Pada penelitian ini didapatkan dua pemeriksaan laboratorium yang positif terbanyak (62,9\%), yaitu aCL dan aPS. Dari penelitian ini, didapatkan pada pasien yang dicurigai APS tetapi memiliki hasil negatif terhadap aCL, anti- $\beta 2 G P I$, dan $L A$, ternyata sebanyak 5 (18,5\%) pasien memiliki hasil positif pada pemeriksaan aPS.

Kesimpulan: Seluruh pasien hamil yang normal tidak menunjukkan hasil pemeriksaan klasik dan aPS positif. Sementara itu, pasien yang dicurigai APS, hanya 20\% yang menunjukkan hasil aPS positif dengan hasil pemeriksaan klasik negatif.

[Maj Obstet Ginekol Indones 2016; 4-3: 138-141]
\end{abstract}

Kata kunci: antiphospatidylserine, antiphospolipid syndrome

Correspondence: Angga J Suryadi. Jalan Kedele Raya No.18 Bojong Indah Jakarta Barat 11740. Telephone: 081806385737. E-mail: anggajsuryadi@yahoo.com

\section{INTRODUCTION}

Intra Uterine Fetal Death (IUFD) was defined as a fetal death which occurs in more than 20 weeks of gestational age. Several factors underlie this condition such as fetus (chromosomal abnormality, infection), placenta (placental abruption, placental insufficiency), or maternal (metabolic disorder hypercoagulability state, etc.). ${ }^{1}$

Hypercoagulable state is one of IUFD common causes from maternal factors which are due to the antiphospholipid syndrome (APS). This syndrome is an autoimmune disease characterized by the presence of antiphospholipid antibodies (aPL) and at least one of clinical manifestations, such as arterial or venous thrombosis or fetal death. ${ }^{2}$ The incidence of APS in women experiencing IUFD was quite high around $20-40 \% .^{3,4}$ The perinatal mortality rate in Indonesia was generally about 77 per 1,000 live births whereas 30 stillborn fetuses were caused by APS. ${ }^{5}$ 
The high incidence of IUFD due to APS makes us to improve the knowledge in diagnosing and performing subsequent management. To diagnose APS, it takes at least 1 clinical criteria namely the presence of one or more unknown causes from fetal deaths at the over 10 weeks of gestational age and supported by laboratory criteria which is the presence of aPL. 2,6,7 There is variety of already known aPL, such as lupus anticoagulant (LA), anticardiolipin (aCL), antiphosphatidylserine (aPL), antiphosphatidylethanolamine (aPE), many more. ${ }^{8}$

The LA and aCL antibodies are first discovered to diagnose APS. One of the screening for LA was through the examination of activated partial thromboplastin time (aPTT). ${ }^{2}$ Meanwhile, the examination of aCL has progressed from time to time. Many studies have shown that aCL was not directly bind to the negatively charged phospholipids, but it stuck to the beta-2 Glycoprotein I $(\beta 2 \mathrm{GPI})$, a plasma protein or "cofactor" which was attached directly to negatively charged phospholipids. $^{3}$

However, patients sometimes show negative classic examination results (aPL aCL, anti- $\beta 2 \mathrm{GPI}$, and LA) in clinically suspected APS. Thus, some experts put those patients in the category of seronegative APS. ${ }^{9}$ Meanwhile, other experts are opposite to the above categories which they suggests that it is caused by aPL contained on the patient instead of an antibody to cardiolipin, and $\beta 2 \mathrm{GPI}$; however, the antibodies to phosphatidylserine (aPL) is part of the inner cell membrane. ${ }^{10,11}$ Study by Matzner, et al. stated that aPL was most often identified as the aPS (20.5\%) and aPE (19.1\%). ${ }^{12}$ Therefore, this study aims to compare the classic examination results of antiphospholipid (aPS) and antiphospatidylserine (aPL) antibody profile to establish the diagnosis from suspected antiphospholipid antibody syndrome (APS) patient in order to state the subsequent treatment strategies.

\section{METHODS}

This study was conducted with a descriptive crosssectional design at outpatient clinics of dr. Cipto Mangunkusumo Hospital (RSCM) from January to December 2015. The laboratory test was taken in Clinical Pathology laboratory RSCM/Faculty of Medicine Universitas Indonesia (FKUI) and Prodia laboratory. The inclusion criteria for the group of normal pregnancy were the one who never expe- rienced any of the Sydney criteria; while, group of APS were the patients suspected of APS (fetus death at more than 10 weeks of gestational age) in accordance with one of the clinical criteria for APS (revised in 2006 in Sydney). The exclusion criteria for normal pregnancies were women having experienced one or more clinical episodes of arterial thrombosis, venous or small blood vessels in the tissue or any organ; and patients with infection (fever, or other symptoms of infection). The exclusion criteria for APS were patients with genetic abnormalities (abnormal morphology of the parents); fetus with abnormalities (confirmed by direct examination and the results of ultrasonography); patients with the quality of the gametes were not good (to be seen on the patients aged $>35$ years old); patients with metabolic disorders (elevated blood sugars more than 200). We did the consecutive sampling for all patients who come in and meet the inclusion criteria in the study until the required number of subjects met.

\section{RESULTS}

In this study, we got 54 patients who met the inclusion criteria as study subjects. Of the 54 patients, 27 patients had normal pregnancy and 27 patients with suspected APS. As seen in Table 1, all normal pregnant patients did not have any positive of classic examination (LA, aCL and anti- $\beta 2 \mathrm{GPI}$ ) and aPS.

Table 1. Classic aPL Examination Profile (aCL, anti- $\beta 2 \mathrm{GPI}$, and LA), and aPS in Normal and Suspected APS Patients

\begin{tabular}{|c|c|c|}
\hline $\begin{array}{c}\text { Antibody } \\
\text { Examination }\end{array}$ & $\begin{array}{c}\text { Normal P;regnancy } \\
(\mathrm{n}=27) \\
\mathrm{n}(\%)\end{array}$ & $\begin{array}{c}\text { Suspected APS } \\
(n=27) \\
n(\%)\end{array}$ \\
\hline \multicolumn{3}{|l|}{ LA } \\
\hline Normal & 27 (100) & $25(92.5)$ \\
\hline Prolonged & $0(0)$ & $2(7.5)$ \\
\hline \multicolumn{3}{|l|}{$\mathrm{aCL}$} \\
\hline Negative & 27 (100) & $17(62.9)$ \\
\hline Positive & $0(0)$ & 11 (37.1) \\
\hline \multicolumn{3}{|l|}{ anti- $\beta 2 \mathrm{GPI}$} \\
\hline Negative & 27 (100) & $20(74.1)$ \\
\hline Positive & $0(0)$ & 7 (25.9) \\
\hline \multicolumn{3}{|l|}{ aPS } \\
\hline Negative & 27 (100) & 17 (62.9) \\
\hline Positive & $0(0)$ & $11(37.1)$ \\
\hline
\end{tabular}


In patients with suspected APS, 11 (37.1\%) patients had positive aCL examination, 7 (25.9\%) patients had positive anti- $\beta 2 \mathrm{GPI}$ examination, and 11 $(37.1 \%)$ patients had positive aPS examination. We tried to look at the classic cross-examination of aPL (aCL, anti- $\beta 2 \mathrm{GPI}$, and LA), and aPS in patients suspected of having APS (results not normal or positive). From this study, it was found in 2 (7.5\%) patients having positive cross between LA and $\mathrm{aCL}$, LA and anti- $\beta 2$ GPI, as well as LA and aPS. The most positive aPL of cross-examination result was between aCL and aPS (25.9\%) (Table 2).

\section{DISCUSSION}

In patients with suspected APS, 11 (37.1\%) patients had positive aCL examination, 7 (25.9\%) patients had positive anti- $\beta 2 \mathrm{GPI}$ examination, and 11 $(37.1 \%)$ patients had positive aPS examination. We intend to compare the aPL level of subjects suspected APS with normal pregnant subjects which aims to prove that the levels of aPL in normal pregnancy will not increase.

From this study, it was found in 2 (7.5\%) patients had a positive cross between LA and aCL, LA

Table 2. Cross-examination Profile of Classic aPL Examination (aCL, anti- $\beta 2$ GPI, and LA) and aPS in Suspected APS Patients (abnormal or positive result)

\begin{tabular}{ccccc}
\hline \hline Examination & LA n (\%) & aCL $\mathbf{n}(\%)$ & anti- $\beta$ 2GPI n (\%) & aPS n (\%) \\
\hline LA n (\%) & & $2(7.5)$ & $2(7.5)$ & $2(7.5)$ \\
aCL $\mathbf{n}(\%)$ & & $3(11.1)$ & $7(25.9)$ \\
anti- - 22GPI n (\%) & & & $3(11.1)$ \\
aPS n (\%) & & & \\
\hline \hline
\end{tabular}

Table 3. Classic aPL Examination Profile (aCL, anti- $\beta 2 \mathrm{GPI}$, and LA), and aPS in Suspected APS Patients (only one positive examination)

\begin{tabular}{lc}
\hline \hline Antibody Examination & Suspected APS n (\%) \\
\hline LA & $2(92.5)$ \\
aCL & $11(62.9)$ \\
anti- $\beta 2$ GPI & $7(74.1)$ \\
aPS & $11(62.9)$ \\
\hline \hline
\end{tabular}

In this study, two most positive laboratory result (62.9\%) were aCL and aPS (Table 3). From this study, it was found that in patients with suspected APS, it depicted the negative result against aCL, anti- $\beta 2 \mathrm{GPI}$, and LA; nevertheless, it showed the positive result on aPS examination as many as five (18.5\%) patients (Table 4).

Table 4. The Proportion of Patients who were Clinically Suspected of Having APS which Had Negative aPL Classic Examination Results (aCL, anti- $\beta 2 \mathrm{GPI}$, and LA), but Positive aPS Result

\begin{tabular}{lc}
\hline \hline Antibody Examination & Suspected APS n (\%) \\
\hline aPS & $5(18.5)$ \\
\hline \hline
\end{tabular}

and anti- $\beta 2 \mathrm{GPI}$, as well as LA and aPS. This was because only two patients were positive for LA examination. However, sometimes, patients with clinically suspected APS has negative result of classic examination aPL (aCL, anti- $\beta 2 \mathrm{GPI}$, and LA). Some researchers put it in the category of seronegative aPS. ${ }^{9}$ The diagnosis of seronegative antiphospholipid syndrome (SN-APS) is used in patients with clinical manifestations leading to the APS, but classic examination results of aPL (aCL, anti- $\beta 2 \mathrm{GPI}$, and LA) are persistently negative. Until now, the best management of these patients is still unclear. Examination of aPL in addition to classical examination may improve the ability to diagnose APS. However, the availability of aPL in routine laboratory examination is still limited. Patients with typical clinical manifestations of APS, it can have negative results on the examination of LA including IgG and IgM aCL and anti- $\beta 2 \mathrm{GPI}$. However, there are several considerations which some patients with negative results on classic examination may have antibodies against other phospholipid membranes, such as phosphatidylserine (PL), phosphatidic acid (PA), phosphatidylinositol (PI), phosphatidylethanolamine (PE) which are not included in the examination of blood routine. ${ }^{9,10,13}$ This study investigated the antibodies to phosphatidylserine (PS) as a part of the inner cell mem- 
brane. ${ }^{10,11}$ From this study, it was found that in patients with suspected APS, but having negative result against aCL, anti- $\beta 2 \mathrm{GPI}$, and LA, it turned out as much $5(18.5 \%)$ patients having positive results on aPS examination (Table 4). This was consistent to study conducted by Matzner, et al. which showed aPL as the most frequently identified antibody and followed by aPS. ${ }^{12}$

The diagnosis of SN-APS is an important issue for the clinician to decide additional examination in diagnosing APS. If the classic examination has a negative result and a thorough evaluation of genetic and acquired conditions leading to thrombosis can be ruled out, we need the additional examination. In the future, it is possible that aPL as the additional examination will be included into the criteria. ${ }^{9,11}$

The strength of this study was that we tried to see the profile of clinically APS suspected patient who pointed out the negative of standard laboratory result, but positive result of APS. Unfortunately, the limitation of this study was we had not done the repeated serology examination after 12 weeks applied as gold standard. The study did not examine patients who had a trip of APS positive test results and did not review the outcome of pregnancy.

\section{CONCLUSION}

All normal pregnant patients do not have any positive classic examination and aPS. Meanwhile, in patients with suspected APS, less than $20 \%$ patients show positive result of aPS with negative result in classic laboratory examination.

\section{REFFERENCES}

1. Cunningham FG, Leveno KJ, Bloom SL, Hauth JC, Rouse DJ, Spong CY. Diseases and injuries of the fetus and newborn. Williams Obstetrics. 23 ${ }^{\text {rd }}$ ed: The McGraw-Hill Companies; 2010.

2. Hanly JG. Antiphospholipid syndrome: an overview. CMAJ. 2003; 168(13): 1675-82.

3. Chamley L. Antiphospholipid antibodies: biological basis and prospects for treatment. J Reprod Immunol. 2002; 57: 185-202.

4. Greaves M, Cohen H, MacHin S, Mackie I. Guidelines on the investigation and management of the antiphospholipid syndrome. Br J Haematol. 2000; 109(4): 704-15.

5. Gambaran faktor yang menyebabkan kematian janin dalam kandungan di RSU Dr. Pringadi Medan periode Januari 2007-Desember 2007, (2008).

6. Malaviya AN. Antiphospholipid (Hughes) syndrome: a review with update. J Rheumatol Suppl. 2003; 6: 160-9.

7. Tektonidou M. Antiphospholipid syndrome. Orphanet Encyclopedia. 2004: 1-6.

8. McIntyre JA, Wagenknechta DR, Faulka WP. Antiphospholipid antibodies: discovery, definitions, detection and disease. Prog Lipid Res. 2003; 42: 176-237.

9. Cervera R, Conti F, Doria A, Iaccarino L, Valesini G. Does seronegative antiphospholipid syndrome really exist? Autoimmun Rev. 2011;doi:10.1016/j.autrev.2011.10.017.

10. Wong RCW, Favaloro EJ. Clinical Features, Diagnosis, and Management of the Antiphospholipid Syndrome. Semin Thromb Hemost. 2008; 34(3): 295-304.

11. Egerer K, Roggenbuck D, Büttner T, Lehmann B, Kohn A, Landenberg Pv, et al. Single-step autoantibody profiling in antiphospholipid syndrome using a multi-line dot assay. Arthritis Res Ther. 2011; 13(4): R118.

12. Matzner W, Chong P, Xu G, Ching W. Characterization of antiphospholipid antibodies in women with recurrent spontaneous abortions. J Reprod Med. 1994; 39(1): 1-4.

13. Lopez LR, Dier KJ, Lopez D, Merrill JT, Fink CA. Anti- $\beta 2$-glycoprotein I and antiphosphatidylserine antibodies are predictors of arterial thrombosis in patients with antiphospholipid syndrome. Am J Clin Pathol. 2004; 121: 142-9. 